\title{
Dynamical of the Truth: Political Poetry Contestation during Jakarta Gubernatorial Election 2016-2019
}

\author{
Yoseph Yapi Taum, Faculty of Literature, Universitas Sanata Dharma. E-mail: yosephyapi@usd.ac.id
}

\begin{abstract}
In Indonesia, the years 2016 to 2019 have become known as the dynamical Years of Politics. They are years in which national energy and concern has been oriented towards election and leadership issues. In 2016, public concern was drawn to the Jakarta Gubernatorial Election, in which the incumbent Basuki Tjahaja Purnama (better known as Ahok) was defeated. Although this was a local election, the Jakarta Gubernatorial Election drew national and international both because Jakarta is the capital of Indonesia and because Ahok's leadership style had become a subject of public discussion. Although the election of new leaders is commonplace in democracy, in Indonesia these political activities were not simple political practice. The Jakarta Gubernatorial Election (2017) and the Indonesian Presidential Election (2019) sharply polarized Indonesian society. These elections involved not only the contestation of individual candidates, but of ideologies. Contestations occurred not only in formal politics, but also in art; poetry was a particularly significant medium of contestation. This study shows that politicians used poetry as a tool to promote their own ideology. It also finds that the substantial 'truth' of a poem was not as important as the beliefs espoused within them. As such, the Indonesian people have entered a post-truth era, with post-truth and ideologies producing a postmodern cultural model, a hyperreal society incapable of distinguishing between truth and fantasy. In this model, "awareness" (ideology) defines "reality".
\end{abstract}

Keywords--- Political Contestation, General Elections, Ideology, Power, Post-truth, Hyperreality.

\section{Introduction}

The use of poetry as a tool and means of political campaigning is not a new phenomenon in Indonesia. When nationalism first emerged in the archipelago, Indonesia's future political leaders were already using poetry for their ideological contestations. In 1920, when Indonesia was still under Dutch colonial rule, Sukarno wrote a poem titled "Ibumu Indonesia Teramat Cantik" (Your Mother, Beautiful Indonesia) (Sularto, 2004). This poem praises Indonesia's natural and cultural beauty: its sky, mountains, seas, fields, valleys, food, and people. As one of Indonesia's founding fathers, Sukarno urged his people to serve their homeland and their nation: "Maka tidak lebih dari wajibmu apabila kaти memperhambakan, //membudakkan dirimu kepada Ibumu Indonesia,//menjadi putra yang mengikhlaskan setiamu kepadanya.//" (Thus it is no less than your duty to serve // to dedicate yourself to your mother, Indonesia // to become a son who sincerely surrenders himself to her).

Sukarno's depiction of Indonesia's beauty is imbued with a strong sense of nationalism. God the Creator, however, is not emphasized in this work. As such, Muslim groups (represented in this case by Hajji Agus Salim) produced poems that advanced their own ideology. In Agus Salim's work, Indonesia's beauty is attributed solely to God (Allah Ta'ala). This can be seen, for example, in the poem "Tanah Air Kita" (Our Homeland), which emphasized that Islam was the bond that united Indonesia's people: "Apa kesatuan kita?//Pakaiankah atau rupa//Nyanyian atau suara//Tidak itu terutama//Islam agama yang mulia//Islam agama kita berbahagia.// (What gives us unity? // Our clothes or form // our songs or voices // That is not it // Islam, a noble religion // Islam, our happy religion).

The contestation of nationalist and religious ideologies, as evident in the above-quoted excerpts from the poems by Sukarno and H. Agus Salim, is done using polite and complementary language. However, poems have also been used in negative political campaigns, especially those intended as election propaganda (Fodouop \& Greene, 2018). Such works create conflict and enmity between candidates and their supporters. In the presidential election conducted by the Tibetan diaspora community, poems and the (mis)information contained within contributed to one candidate's electoral victory (Wangchuk, 2018).

A careful reading of the history of Indonesian literature shows that political and social phenomena have been integral to its development. Socio-political moments have marked the beginning of new eras in Indonesian literature, as seen in the Japanese Generation (marked by the Japanese occupation of the Indonesian archipelago), the Generation of ' 45 (marked by Indonesia's proclamation of independence on August 17, 1945), the Generation '66 
(marked by the political turmoil that followed the national tragedy of September 30, 1965), and the Generation of 2000 (marked by the beginning of Indonesia's political reform). The customary periodization of Indonesian literature, thus, highlights that Indonesia's literary history cannot be separated from its socio-political history.

General elections are important democratic mechanisms as they offer a means of peacefully transferring leadership to individuals who have received the largest percentage of the vote. They are thus central pillars of democracy, both mature and vulnerable ones (Mesfin, 2008). As such, International IDEA on Electoral Integrity emphasizes the need for integrity in elections as the only means of reinforcing democracy, continuing developing, and guaranteeing individual and public security (Sisk, 2017). However, in new and post-conflict democracies, elections have the potential to create further conflict, destabilize governments, and discredit democratic processes. In such cases, general elections are thus fiercely contested as candidates and their allies seek access to power and resources (Kühne, 2010).

In 2017, the Jakarta Capital Region (henceforth Jakarta) held its gubernatorial election. Although Jakarta is but one of Indonesia's 35 provinces, the election in the country's capital drew national attention. The 2017 election was thus very heated, with the people of Jakarta and Indonesia being sharply polarized and drawn into confrontation. In this election, poetry was often used as a political tool. This practice is examined in the current study, which exposes the ideological contestations manifested through poetry (2016-2019) (Anggraeni, 2018).

Previous studies similar to this study were conducted by Patji (Patji, 2015). In his article entitled "Political Poetry During the 2014 Indonesian Presidential Campaign," Patji highlighted the poems used in political contestation in the 2014 election campaign. There are two competing political party forces, namely the Gerindra Party which supports Prabowo Subianto /M. Hatta Radjasa versus the Partai Demokrasi Indonesia Perjuangan (PDIP) which supports Joko Widodo (Jokowi)/M. Jusuf Kalla. In that article, Patji revealed the phenomenon of "political poetry" which received responses from three parties namely political actors, literary groups, and the wider community. From this very broad response, Patji concluded that the use of poetry as a "new" strategy in political campaigns was important to soften the tension of the campaign so as not to reach the peak of tension.

This study does not reveal the responses of the three groups to political poetry as was done by Patji. This study focuses on poetry texts and their unconscious political meaning in political contestation in the 2016-2019 governor election campaign in Jakarta.

\section{Theoretical Background}

This study applied the theory of political criticism in literary studies, as revealed by Jameson and Eagleton. Political criticism is also recognized in the field of cultural studies, such as introduced by Birmingham University's through the Center for Contemporary Cultural Studies (CCCS).

Fredric Jameson, in his The Political Unconscious: Narrative as a Socially Symbolic Act (1981), emphasized the need for political criticism in literature studies. He wrote that all texts have their own social, historical, and political resonances. Literary texts are but the surfaces of seas of historical events. As such, it is important to identify the political subconsciousness of literary texts in order to understand them with all of their historical contradictions (Jameson, 1981).

In his book Literary Theory: An Introduction, Terry Eagleton (1983) expressed disappointment in 20th-century intellectuals' obsession with using the language of literary texts to contextualize life issues (Eagleton, 1983: 97). Real-life issues cannot be understood solely through matters of language and aesthetics. Instead, Eagleton argues that scholars must attempt to define the link between literature and ideology. As with Jameson, Eagleton thus underscored the importance of political critique in literary studies. Eagleton understands politics as all means of regulating and organizing society, and as such as integrally involving the practice of power and specific ideologies. Literary scholars must thus produce a definition of ideology that enables them to understand literature as a concrete and fundamental part of human life rather than an abstract idea (Eagleton, 1983).

Such thoughts have been an undercurrent of postmodern theories, including those used in cultural studies. Cultural studies offer a critical approach, one that applies a moral agenda within the academic realm in order to improve the performance of culture. In this paradigm, culture - something dominated by 'coercive' interests and powers - must be negotiated. Through cultural studies, fields of study that have been subjugated or ignored have been revivified, resulting in what Foucault identifies as the insurrection of the subjugated knowledges (Taum, Sastra dan Politik: Representasi Tragedi 1965 dalam Negara Orde Baru , 2015). 
The pioneers of cultural studies at Birmingham University's Centre for Contemporary Cultural Studies (CCCS), including Raymond Williams, Richard Hoggart, and Stuart Hall, hypothesized that nothing is apolitical (Barker, 2000). Literature, as a cultural product, is thus viewed as an arena of ideological contestation. Scholars examine the means through which culture is produced through ideological contestations (Barker, 2000). Through cultural studies, scholars seek to understand the patterns of dominance and hegemony in society. From a cultural studies perspective, the history of Indonesian literature may be understood as processes through which intellectuals have attempted to contest their ideologies and assert their dominance in order to access and practice power.

\section{Research Method}

Researcher has collected all the poems that recounted to the Jakarta governor election from all mass media published from 2016 to 2019. Researcher found seven poems written by five authors in Indonesia. One of the most dominant writers named Fadli Zon wrote three poems. He is a member of the Gerindra Party who supports one of the candidates for governor. Whereas the other four writers each wrote one poem. These four people are not members of political parties. The poetries are listed at Table 1 below.

Table 1: List Poems dealing with the 2017 Jakarta Gubernatorial Election

\begin{tabular}{|c|c|c|c|c|}
\hline No & Title & Author & Date & Notes \\
\hline 1. & $\begin{array}{l}\text { "Tukang Gusur" } \\
\text { (The Evictor) }\end{array}$ & $\begin{array}{l}\text { Fadli } \\
\text { Zon }\end{array}$ & $\begin{array}{l}\text { September 23, } \\
2016\end{array}$ & $\begin{array}{l}\text { This poem was read during the announcement of the } \\
\text { Anies-Sandiaga at the home of Prabowo Subianto. In } \\
\text { this poem, Fadli did not explicitly identify the "evictor" it } \\
\text { discussed. }\end{array}$ \\
\hline 2. & $\begin{array}{l}\text { "Tak Pernah } \\
\text { Terbayang" (Never } \\
\text { Imagined) }\end{array}$ & $\begin{array}{l}\text { Fadli } \\
\text { Zon }\end{array}$ & $\begin{array}{l}\text { November 5, } \\
2016\end{array}$ & $\begin{array}{l}\text { This poem was written in response to the second Action } \\
\text { in Defense of Islam (Aksi Bela Islam) on November 4, } \\
\text { 2016. Fadli had participated in this protest. }\end{array}$ \\
\hline 3 & $\begin{array}{l}\text { "Sajak Sang } \\
\text { Penista" (A } \\
\text { Blasphemer's } \\
\text { Poem) }\end{array}$ & $\begin{array}{l}\text { Fadli } \\
\text { Zon }\end{array}$ & $\begin{array}{l}\text { February 2, } \\
2017\end{array}$ & $\begin{array}{l}\text { This poem was written in response to the "blasphemy" } \\
\text { spoken by Basuki Tjahaja Purnama at the Seribu Islands } \\
\text { on October 6, 2016. It was then transformed into a song } \\
\text { by Ahmad Dhani. }\end{array}$ \\
\hline 4 & $\begin{array}{l}\text { "Puisi untuk } \\
\text { Ahok" (A Poem } \\
\text { for Ahok) }\end{array}$ & $\begin{array}{l}\text { Ade } \\
\text { Irawan }\end{array}$ & $\begin{array}{l}\text { April } 5,2017, \\
\text { on Ade } \\
\text { Irawan's } 80 \text { th } \\
\text { birthday }\end{array}$ & $\begin{array}{l}\text { This poem depicts Ahok as an ordinary person who was } \\
\text { subject to unjust treatment and imprisoned for his } \\
\text { willingness to fight against greed and hypocrisy. }\end{array}$ \\
\hline 5 & $\begin{array}{l}\text { "Papan Bunga Balai } \\
\text { Kota" (The Flower } \\
\text { Boards at City Hall) }\end{array}$ & $\begin{array}{l}\text { Julia } \\
\text { Daniel } \\
\text { Kotan }\end{array}$ & 2017 & $\begin{array}{l}\text { This poem was included in the anthology Kita Adalah } \\
\text { Indonesia (We Are Indonesia), which includes works by } \\
25 \text { poets. Not only expressing disappointment in Ahok's } \\
\text { ultimate fate, it also honors his performance as governor. } \\
\text { Several poems in this anthology deal with the Jakarta } \\
\text { gubernatorial election. }\end{array}$ \\
\hline 6 & $\begin{array}{l}\text { "Puisi untuk Ahok" } \\
\text { (A Poem for Ahok) }\end{array}$ & $\begin{array}{l}\text { Rizal } \\
\text { Kyoto }\end{array}$ & $\begin{array}{l}\text { December 16, } \\
2017\end{array}$ & $\begin{array}{l}\text { This poem was written for Ahok while he was } \\
\text { imprisoned. The poet viewed Ahok as a warrior fighting } \\
\text { against all form of hypocrisy. }\end{array}$ \\
\hline 7 & $\begin{array}{l}\text { "Tetap Mantan } \\
\text { Terindah" (Still the } \\
\text { Best Ex) }\end{array}$ & $\begin{array}{l}\text { Wanda } \\
\text { Ponika }\end{array}$ & $\begin{array}{l}\text { February 14, } \\
2019\end{array}$ & $\begin{array}{l}\text { This poem voices pride in Ahok's activities after being } \\
\text { released from prison. }\end{array}$ \\
\hline
\end{tabular}

In analysing ideological contestations, studies of texts may use several methods, including the archeological method, the symptomatic reading method, and the thick description method (Taum, 2015). This study uses the thick description method, which was first proposed by Geertz (1998: 1253-1278) as a means of understanding the cultural ideas and concepts underlying cultural phenomena. This method is intended to enable scholars to excavate layers of meaning and the complex cultural codes underlying them. 'Thick description' focuses on elements that, although they appear unimportant, contain significant detail about cultural praxes (Geertz, 1973; Geertz, 1998). By focusing on these details, it is hoped that researchers can explore and reveal the interactions between various discourses and institutions, communities, and other cultural elements (Bressler, 2007). Furthermore, this method is hoped to reveal the contradictive forces involved in various literary discourses (Lin, 2019). 


\section{Results and Discussion}

The lengthy process through which the Governor of Jakarta was elected began with the registration of candidates on September 21-23, 2016. Three pairs of candidates were formally registered with the General Elections Commission, Jakarta: 1) Basuki Tjahaja "Ahok" Purnama and Djarot Saiful Hidayat; 2) Agus Harimurti and Sylviana Murni; and 3) Anies Baswedan and Sandiaga Uno.

In October 2016, the Indonesian Survey Association (Lingkaran Survei Indonesia, LSI) announced the results of its survey regarding these candidates' electability. It reported that Ahok and Djarot had an electability of 31.4\%, higher than Anies-Sandiaga (21.1\%) and Agus-Sylviana (19.3\%). This was attributed to general public satisfaction with the performance of the incumbent, which reached 71.9\% according to a Charta Politica survey (Nailufar, 2017) or $73 \%$ according to a LSI survey (Ramdhani, 2017).

Earlier surveys had found that Ahok-Djarot had an electability of 59.3\% (March 2016) and 49.1\% (July 2016) (Saroh, 2016). Why had their electability decreased to $31.4 \%$ by October 2019 ? This can be traced back to October 6, 2016, when Buni Yani uploaded a video clip that drew the attention of Muslims throughout Indonesia and resulted in widespread protests demanding that Ahok be punished for his remarks. This response was exacerbated by a statement by the Indonesian Council of Ulamas (Majelis Ulama Indonesia, MUI) that labelled Ahok's statements as blasphemy; he was subsequently charged with blasphemy.

Ultimately, Ahok did not only lose the election-receiving $42.04 \%$ of votes to the $57.96 \%$ received by AnisSandi in the second round of voting — but was also sentenced to two years imprisonment for blasphemy. "We find that Basuki Tjahaja Purnama, also known as Ahok, has been convincingly proven to have committed the crime of blasphemy and sentence him to two years imprisonment," said the judge. With this statement, Ahok's statements were asserted to have violated Article 156a of the Indonesian Criminal Code (KUHP). The former governor also received a heavier prison sentence than demanded by the prosecutor, who had sought one year of imprisonment and two years of probation. Ahok was thus transported directly from the court room to prison. Negative verbal reactions about Indonesia's judiciary comes from all over the world (Hasna Nurhaliza, 2019).

Following the court's decision, Ahok's supporters in Jakarta, around Indonesia, and around the world established a strong sense of solidarity. The Jakarta City Hall was decorated with thousands of red and white balloons, flower bouquets, and candles. More flower bouquets were sent to the National Monument (better known as Monas). Similar activities were undertaken throughout Indonesia, as well as in several foreign countries. In the midst of these heated contestations, poems were used as campaign propaganda and as a means of ridiculing opponents.

This is the background and foreground of the political atmosphere of the Jakarta gubernatorial election which produces those political poetries. The following will be present the results of the analysis of the poems.

\section{Ahok the Evictor}

Before Ahok was labelled a "blasphemer", he was often attacked as an "evictor", as seen in the poem written by Fadli Zon and read before Anies and Sandiaga announced their candidacy. At the time, Fadli Zon was the deputy speaker of the People's Representative Council (Indonesia's lower house) and a member of the Gerindra Party that was backing these candidates.

The first poem that contributed to the discourses regarding the 2017 Jakarta gubernatorial election was "Tukang Gusur", which referred to Ahok's forced eviction of the Kalijodo red-light district in North and West Jakarta in 2016. His government had cited four reasons for clearing the region, which was known as a den of gambling, crime, and prostitution (Haryanto, 2016). First, the Kalijodo district violated Indonesia's Basic Agrarian Law as it was constructed in an open space reserve that should remain undeveloped. Second, according to Minister of Religion Lukman Hakim Saifuddin, prostitution violated religious teachings and the district should be demolished. Third, according to Minister of Social Affairs Khofifah Indar Parawansa, the government would be able to facilitate former sex workers by providing them with professional skills training or factory employment. Fourth, as a gambling den, Kalijodo had become a magnet for those who would coerce Indonesia's security forces or otherwise promote corruption; this was mentioned by Police Commissioner Krishna Murti in his book Geger Kalijodo.

Before the district was cleared, the local government sent several letters of warning to the residents of Kalijodo. At the same time, the Indonesian police and military stated that they would be willing to provide security during eviction activities. Local residents - under the leadership of Daeng Aziz - were staunchly opposed to this plan. Nonetheless, the Jakarta government (with the support of the police and military) continued its forced eviction activities. 
Responding to the disappointment of Kalijodo residents as well as their supporters, Fadli Zon wrote his highly critical "Tukang Gusur".

\begin{tabular}{|c|c|}
\hline TUKANG GUSUR & THE EVICTOR \\
\hline Fadli Zon & Fadli Zon \\
\hline Tukang gusur-tukang gusur. & The evictor, the evictor \\
\hline Menggusur orang-orang miskin. & Evicting the poor \\
\hline Di kampung-kampung hunian puluhan tahun. & From their settlement of decades \\
\hline Di pinggir bantaran Kali Ciliwung. & Along the banks of the Ciliwung River. \\
\hline Di rumah-rumah nelayan Jakarta. & The homes of Jakarta's fishermen \\
\hline Di dekat apartemen mewah, mal yang gagah. & Near luxury apartments, massive malls \\
\hline Semua digusur, sampai hancur. & All evicted, destroyed \\
\hline Tukang gusur, tukang gusur. & The evictor, the evictor \\
\hline Melebur orang-orang miskin. & Wasting the money of the poor \\
\hline Melumat mimpi-mimpi masa depan. & Blunting dreams of the future \\
\hline Membunuh cita-cita dan harapan. & Killing hopes and prayers \\
\hline Anak-anak kehilangan sekolah, & Children losing their schools, \\
\hline bapak-bapaknya dipaksa menganggur. & Fathers left without jobs \\
\hline Ibu-ibu kehabisan air mata. & Mothers bereft of tears. \\
\hline Tukang gusur, menebar ketakutan di Ibu Kota. & The evictor, spreading fear in the Capital. \\
\hline Gayanya pongah bagai penjajah. & A swaggering colonial \\
\hline Caci maki kanan kiri. & Shooting insults left and right \\
\hline Mulutnya serigala penguasa. & Mouth of a wolf \\
\hline Segala kotoran muntah. & All vomit and refuse \\
\hline Kawan-kawannya konglomerat. & Friend of the conglomerates \\
\hline Centengnya oknum aparat. & Triggerman of the security forces \\
\hline Menteror kehidupan rakyat. & Terrorizing the people \\
\hline Ibu Kota katanya semakin indah. & The Capital, beautiful they say \\
\hline Orang-orang miskin digusur pindah. & The poor driven away, evicted \\
\hline Gedung-gedung semakin cantik menjulang. & Fetching buildings reaching high \\
\hline Orang miskin digusur hilang. & The poor driven away, evicted \\
\hline Tukang gusur tukang gusur. & The evictor, the evictor \\
\hline Sampai kapan kau duduk di sana. & How long will you sit there \\
\hline Menindas kaum dhuafa. & Oppressing the destitute \\
\hline Tukang gusur, tukang gusur. & The evictor, the evictor \\
\hline Suatu masa kau menerima karma. & One day you'll get yours \\
\hline Pasti digusur oleh rakyat Jakarta. & Evicted by the people of Jakarta. \\
\hline
\end{tabular}

This poem refers to an undefined 'somebody' as the evictor. In the case of Kalijodo, however, it was clear that Ahok was responsible for clearing and demolishing the Kalijodo District. In this poem, Ahok is presented implicitly as an evictor, one who not only brought suffering to the poor but also spread fear throughout the city. He is also described as "a swaggering colonial", "shooting insults left and right", having the "mouth of a wolf" that spreads "vomit and refuse". He is identified as "friend of the conglomerates" and "triggerman of the security forces". All of these exploit the suffering of the people of Kalijodo and thereby conduct character assassination.

\section{Ahok as a Blasphemer}

Ahok's opponents found new ammunition for their attacks after Buni Yani uploaded a video clip that showed Ahok making a statement that was viewed as insulting Islam. This statement, delivered at the Seribu Islands during a speech intended to promote a carp farming program, (Fauzi, 2016), is quoted below:

"It's common, ladies and gentlemen, for them to not vote for me because they have been lied to using Surah AlMaidah 51 and whatnot. That's your right, ladies and gentlemen. If you feel that you can't pick me because you're afraid you'll go to Hell, that you're being deceived, that's fine. That is your own prerogative. This program (the provision of funding for carp farming) will keep going. So you don't need to worry that your conscience won't let you vote for Ahok."

Buni Yani uploaded an excerpt from this speech to his Facebook account under the title "Penistaan terhadap Agama?" ("Blaspheming Religion?"). In his transcript of the speech, Buni Yani removed the word pakai (using), giving the impression that Ahok had implicitly identified the Quranic verse itself as deceitful. This was followed by intense opposition to Ahok. The Islamic Defenders Front (Front Pembela Islam, FPI) and Council of Indonesian Ulama (Majelis Ulama Indonesia, MUI) of South Sumatra reported Ahok to the police. These were but some of the fourteen reports that were submitted, which suggest significant public pressure and political tensions. 
Shortly thereafter, MUI (led at the national level by Ma'ruf Amin) issued a statement that formally identified Ahok as insulting the Quran and Islamic scholars. The council also asked the police to immediately deal with Ahok. Afterwards, the National Movement for Enforcing the MUI Fatwa (Gerakan Nasional Pengawal Fatwa MUI; GNPF MUI) was established by Bachtiar Nasir to enforce the fatwa. Various protests followed shortly thereafter. These included numerous a series of protests, labelled "Actions in Defense of Islam" (Aksi Bela Islam), that were mobilized by FPI and its leader Rizieq Shihab and demanded Ahok's arrest. The first protest was held on October 14, 2016; further demonstrations were held on November 4, 2016; December 2, 2016 (popularly known as 212); February 11, 2017; February 21, 2017; March 31, 2017; and May 5, 2017) (see Wikipedia, 2017, "Aksi Bela Islam"). These protests inspired Fadli Zon to write a poem titled "Tak Pernah Terbayang" (Never Imagined). It positions itself as the cry of a people insulted.

\begin{tabular}{|c|c|}
\hline $\begin{array}{l}\text { TAK PERNAH TERBAYANG } \\
\text { tak pernah terbayang } \\
\text { jutaan rakyat berbaris datang } \\
\text { dari gang sempit, kampung, kompleks perumahan } \\
\text { dari apartemen, blok petakan sampai lokasi gusuran } \\
\text { semua sepakat menuntut keadilan }\end{array}$ & $\begin{array}{l}\text { NEVER IMAGINED } \\
\text { Never imagined } \\
\text { Millions of people filing out } \\
\text { From the narrow alleys, villages, housing complexes } \\
\text { From the apartments, blocks, and evicted lands } \\
\text { All uniting to demand justice }\end{array}$ \\
\hline $\begin{array}{l}\text { tak pernah terbayang } \\
\text { jutaan umat berbaju putih berwajah bersih } \\
\text { memenuhi mushola, masjid, dan lapangan } \\
\text { berbekal samudera keikhlasan } \\
\text { saling berbagi penuh persaudaraan } \\
\text { menggalang jaringan kekuatan } \\
\text { semua sepakat membela keyakinan }\end{array}$ & $\begin{array}{l}\text { Never imagined } \\
\text { Millions of faithful, dressed in white, faces clean } \\
\text { Filling the prayer rooms, mosques, and fields } \\
\text { Armed with a sea of devotion } \\
\text { Sharing together in brotherhood } \\
\text { Establishing networks of power } \\
\text { All to defend their faith }\end{array}$ \\
\hline $\begin{array}{l}\text { tak pernah terbayang } \\
\text { para ulama, habaib, dan kyai turun ke jalan } \\
\text { bersorban keberanian } \\
\text { semangat membalut perjuangan } \\
\text { shalawat sepanjang perjalanan } \\
\text { semua sepakat mendudukkan kebenaran }\end{array}$ & $\begin{array}{l}\text { Never imagined } \\
\text { The ulama, habibs, and kyai descending to the streets } \\
\text { Turbaned in courage } \\
\text { Passionate in their struggle } \\
\text { Praying in the streets } \\
\text { All agreeing to assert the truth }\end{array}$ \\
\hline $\begin{array}{l}\text { hukum telah diinjak-injak penguasa } \\
\text { aparat belepotan lindungi sang penista } \\
\text { media komprador siarkan dusta } \\
\text { fitnah berceceran di dunia maya } \\
\text { tuan rumah Istana pergi entah kemana }\end{array}$ & $\begin{array}{l}\text { Law has been trampled by those in power } \\
\text { The apparatus protecting the blasphemer } \\
\text { Compromised media spreading lies } \\
\text { Defamation shooting around the internet } \\
\text { The Lord of the Palace gone, who knows where }\end{array}$ \\
\hline $\begin{array}{l}\text { tak pernah terbayang } \\
\text { jutaan manusia teriak lantang } \\
\text { takbir menguasai gelanggang } \\
\text { Allahu Akbar Allahu Akbar Allahu Akbar! } \\
\text { dan lagu Indonesia Raya berkumandang } \\
\text { Bangunlah jiwanya bangunlah badannya } \\
\text { demonstran mengacungkan kepalan tangan } \\
\text { tak peduli lagi segala ancaman } \\
\text { semua sepakat menuntut keadilan }\end{array}$ & $\begin{array}{l}\text { Never imagined } \\
\text { Millions of people shouting plainly } \\
\text { The takbir echoing } \\
\text { God is Great, God is Great, God is Great! } \\
\text { And the song Indonesia Raya ringing } \\
\text { "In body, in spirit, let them all arise" } \\
\text { Demonstrators raising their fists } \\
\text { No longer heeding threats } \\
\text { All uniting to demand justice }\end{array}$ \\
\hline $\begin{array}{l}\text { hari itu kurasakan } \\
\text { denyut nadi revolusi } \\
\text { menggerakkan hati nurani } \\
\text { bersiap melawan tirani }\end{array}$ & $\begin{array}{l}\text { That day I felt } \\
\text { The beat of the revolution } \\
\text { Moving my conscience } \\
\text { To fight against tyranny }\end{array}$ \\
\hline $\begin{array}{l}\text { *Fadli Zon, } 5 \text { Nopember } 2016 \\
\text { Setelah mengikuti Aksi Bela Islam, } 4 \text { Nopember } 2016 .\end{array}$ & $\begin{array}{l}\text { *Fadli Zon, November 5, } 2016 \\
\text { After participating in the Action in Defense of Islam, November 4, } 2016 .\end{array}$ \\
\hline
\end{tabular}

This poem conveys a sense of awe regarding the Action in Defense of Islam, with "millions of people filing out" representing the "beat of the revolution" to "demand justice". Religious nuances are strong in this poem, as seen in the diction and phrasings used. Take, for example, the lines "Never imagined // Millions of faithful, dressed in white, faces clean // Filling the prayer rooms, mosques, and fields // Armed with a sea of devotion ... // The ulama, habibs, and kyai descending to the streets // Turbaned in courage // The takbir echoing // God is Great, God is Great, God is Great!".

Conversely, the poem presents Ahok and his supporters - the media, the security apparatus, and the office holders - very negatively: "Compromised media spreading lies // Oppressing the destitute // spreading fear in the Capital // A swaggering colonial // Shooting insults left and right // Mouth of a wolf // All vomit and refuse // Friend of the conglomerates // The apparatus protecting the blasphemer // Triggerman of the security forces // Law has been trampled by those in power // The Lord of the Palace gone, who knows where // Defamation shooting around the 
internet // a perfect arrogance // cursed oaths // intimidation flowing like the floodwaters // you insulted those at the margins // evicting them without concern // oppressing with an iron fist // corrupted as you pleased // corruption from hospitals through reclamation activities // to fulfill the demands of ambition).

The demonstrators - those who became collectively known as the 212 Movement - are identified as innocents, as people who descended to the streets to demand justice because they felt that their religion had been insulted. Ahok and his regime, conversely, are identified as blasphemers and deceivers. However, the social reality was not as depicted in the poem. Ahok was the victim of political maneuverings that utilized identity politics to remove him from power. It may be concluded, thus, that the poem is partisan, having employed identity politics as a means of attacking its author's political opponent. The sharpest and most explicit attack was put forth in the poem "Sajak Sang Penista" (A Blasphemer's Verse).

\begin{tabular}{|c|c|}
\hline $\begin{array}{l}\text { Sajak Sang Penista } \\
\text { di tengah damai jakarta } \\
\text { kau pamerkan keangkuhan sempurna } \\
\text { sumpah serapah intimidasi } \\
\text { mengalir sederas air banjir } \\
\text { lalu kau cibir orang-orang pinggir } \\
\text { menggusur tanpa basa basi } \\
\text { menindas dengan tangan besi } \\
\text { dan kau seenaknya korupsi } \\
\text { dari rumah sakit hingga reklamasi } \\
\text { memenuhi nafsu ambisi }\end{array}$ & $\begin{array}{l}\text { A Blasphemer's Verse } \\
\text { in the midst of Jakarta's peace } \\
\text { you showed a perfect arrogance } \\
\text { cursed oaths of intimidation } \\
\text { flowing like the floodwaters } \\
\text { then you insulted those at the margins } \\
\text { evicting them without concern } \\
\text { oppressing with an iron fist } \\
\text { and you corrupted as you pleased } \\
\text { from hospitals through land reclamation } \\
\text { to fulfill the demands of ambition }\end{array}$ \\
\hline $\begin{array}{l}\text { di tengah damai jakarta } \\
\text { kau nista ayat-ayat tuhan } \\
\text { al qur'an dituduh alat kebohongan } \\
\text { kaulah yang merobek kebhinekaan } \\
\text { juara pengkhianat pancasila } \\
\text { pemecah belah kerukunan beragama } \\
\text { biang segala adu domba }\end{array}$ & $\begin{array}{l}\text { in the midst of Jakarta's peace } \\
\text { you insulted the verses of god } \\
\text { claimed the Quran is a tool of lies } \\
\text { you shredded the diversity } \\
\text { champion of betraying Pancasila } \\
\text { shatterer of interfaith harmony } \\
\text { cause of all conflict }\end{array}$ \\
\hline $\begin{array}{l}\text { di tengah damai jakarta } \\
\text { kau fitnah lagi kyai dan ulama } \\
\text { serbuan berita palsu hasutan gila } \\
\text { ancaman teror fisik hingga penjara } \\
\text { kau bagai diktator pemilik dunia } \\
\text { menyebar resah ke segala arah } \\
\text { menggalang lautan amarah }\end{array}$ & $\begin{array}{l}\text { in the midst of Jakarta's peace } \\
\text { you defamed the kyai and ulama } \\
\text { spread fake news, crazy incitation } \\
\text { threats of physical terror and prison } \\
\text { you act as a dictator, owner of the world } \\
\text { spreading anxiety all about } \\
\text { stirring the seas of rage }\end{array}$ \\
\hline $\begin{array}{l}\text { kami tahu kau hanya pion berlagak jagoan } \\
\text { di belakangmu pasukan hantu gentayangan } \\
\text { tangan-tangan kotor penguasa komplotan } \\
\text { konspirasi barisan kejahatan } \\
\text { hukum mudah kau beli murah } \\
\text { keadilan punah habis dijarah } \\
\text { demokrasi dikebiri sudah } \\
\text { peluru muntah berhamburan } \\
\text { provokasi pesta kerusuhan }\end{array}$ & $\begin{array}{l}\text { we know you're only a pawn acting like a king } \\
\text { behind you ghost troops rattle their shields } \\
\text { the dirty hands of the powerful } \\
\text { conspiring to commit crime } \\
\text { the law you buy cheaply } \\
\text { justice dead and robbed } \\
\text { democracy castrated } \\
\text { as bullets fly } \\
\text { provoking a feast of chaos }\end{array}$ \\
\hline $\begin{array}{l}\text { tapi ingatlah sang penista } \\
\text { takdir pasti kan tiba } \\
\text { rakyat bersatu tak bisa dikalahkan } \\
\text { doa ulama kobarkan keberanian } \\
\text { umat yang terhina berjihad kebenaran } \\
\text { orang-orang miskin membangun perlawanan } \\
\text { dan tirani pasti tumbang }\end{array}$ & $\begin{array}{l}\text { but remember, o blasphemer } \\
\text { your day will come } \\
\text { a united people undefeated } \\
\text { ulamas' prayers bringing courage } \\
\text { the insulted faithful on a jihad for truth } \\
\text { the poor rising up in opposition } \\
\text { tyranny will fall }\end{array}$ \\
\hline $\begin{array}{l}\text { di tengah damai jakarta } \\
\text { kaulah penabur benih bencana }\end{array}$ & $\begin{array}{l}\text { in the midst of Jakarta's peace } \\
\text { you sowed the seeds of disaster }\end{array}$ \\
\hline Fadli Zon, Jakarta, 2 Februari 2017 & Fadli Zon, Jakarta, February 2, 2017 \\
\hline
\end{tabular}

What labels does Fadli Zon apply to Ahok in this poem? He is presented as the cruelest, most immoral, and most evil human being in existence. He insults the poor, rules with an iron fist, corrupts government funds, and defames religious leaders and - even worse - the holy verses of the Quran. Is this poem, thus, a religious one or a political one? This poem appears to have manipulated religious symbols for political purposes (Babagolzadeh 2017), and is thus intended to assassinate his character. Ultimately, Ahok not only lost the election, but was also sentenced to two years imprisonment.

\section{Ahok as an Honest Leader}

Fadli Zone was not the only person to contribute his poems to Indonesia's public discourses on Ahok. A respected film star, Ade Irawan, wrote a poem that voiced her support and sympathy for Ahok (Irawan, 2017). As 
the governor of Jakarta, Ahok had sought to bring order to Jakarta and eradicate 'hypocrisy and greed'. Facing charges of 'blasphemy', Ahok had openly sought forgiveness: "Even if he sought peace and forgiveness // who would care?' For Ade Irawan, Ahok was an honest leader whose destruction was ordered by a "network of hate" that had bared its "claws". On December 16, 2017, Rizal Kyoto also published a poem titled "Puisi untuk Ahok" (A Poem for Ahok) at kompasiana.com (Kyoto, 2017).

\begin{tabular}{|l|l|}
\hline PUISI UNTUK AHOK & A POEM FOR AHOK \\
Oleh Ade Irawan & By Ade Irawan \\
Dia cuma laki-laki biasa & He is but an ordinary man \\
yang merambah semak liar & Who wandered the wild bush \\
dan sesekali menebas belantara & Sometimes breaking through the thickets \\
kemunafikan dan keserakahan & Of hypocrisy and greed \\
Kalaupun dia coba merajut maaf dan kedamaian & Even if he sought peace and forgiveness \\
siapa yang mau peduli? & Who would care? \\
Karena langkahnya sudah dijegal & Because his steps had been blocked \\
jeruji kebencian & By a network of hate \\
Dan cakar mereka sudah tak sabar & And their claws were anxiously \\
ingin mengoyak kejujurannya & Trying to silence his honesty \\
Kadang aku malu bersimpuh di sajadah & Sometimes I feel ashamed to bow in my sajadah \\
mencari jawabmu dalam tengadah & To find your answers amidst this \\
Tuhan, siapa sesungguhnya pemegang kunci surga? & God, who truly holds the keys to heaven? \\
\hline
\end{tabular}

In this poem, Ade Irawan touches on the religious elements that had been emphasized by Ahok's opponents. Ahok had already apologized, but he had not been forgiven; rather, he had been imprisoned as a result of the machinations of a network of hate. The final lines offer a sort of religious reflection. Ahok's opponents had used their religion as the basis of their attacks. As such, Ade Irawan felt ashamed, wondering who truly held the keys to heaven. She writes, "Sometimes I feel ashamed to bow in my sajadah // To find your answers amidst this // God, who truly holds the keys to heaven?"

The second poem titled "Puisi untuk Ahok" (A Poem for Ahok) was written by Eizal Kyoto. It was dedicated to Ahok, who at the time sat "behind the walls of isolation". For the poet, Ahok was a "warrior who had been ostracized" - a soldier in the war against hypocrisy—and thus should never have been imprisoned. He was a staunch nationalist. "Through your soul and body still flows // A love for this land". These and subsequent lines reveal the poet's pride in Ahok's performance, and a longing for his ability to challenge the dominance of hypocrisy.

\begin{tabular}{|l|l|}
\hline PUISI UNTUK AHOK & A POEM FOR AHOK \\
Rizal Kyoto & Rizal Kyoto \\
Di balik tembok pengasingan kau terbuang & Behind the walls of isolation you're wasted \\
Seorang pejuang perang yang terasingkan & A fighter, warrior ostracized \\
Dalam deru debu peperangan & In the calamity of the battle \\
Melawan segala bentuk kemunafikan & Against all forms of hypocrisy \\
\hline Aku merindu... & I pine... \\
Dari pulau seberang aku manyapamu & From the next island over I greet you \\
Berharap suara ku menembus tembok peraduan & Hope my voice pierces the walls of contestation \\
Meski ku tau disana & Although I am not there \\
Di jiwa dan ragamu tetap terpatri & In your soul and body still flows \\
Rasa cinta pada negeri ini & A love for this land \\
\hline Tak ada lagi umpatan dan maki mu & No longer do your insults and curses come \\
Ketika mereka tak berjalan ke arah yang kau mau & When they fail to move the way you want \\
Tak ada lagi senyum sumringahmu & No longer does your smile shine \\
Ketika puluhan bahkan ratusan mulut mengadu & When dozens and even hundreds of mouths contest \\
Ruangan tempat mu dulu & Your space before \\
Tak lagi terbuka buat mereka & No longer open to them \\
Yang selalu ingin menatap kamu bekerja & Who want to always see you work \\
Tirai tirai kepalsuan kini menghiasi setiap jendela & The curtains of falsehood now decorate every window \\
Tanpa bisa melihat didalam nya apa & Revealing not what lies behind them \\
\hline Kini.... & Now.... \\
Aku... & I... \\
Kami..... & We..... \\
Dan bahkan semua larut dalam rindu & And maybe all are lost in longing \\
Tak sabar menanti engkau kembali & Impatiently awaiting your return \\
Untuk negeri yang kau cintai. & To the land you love \\
\hline
\end{tabular}

\section{Ahok and the Million Candles}

When Ahok was found guilty of blasphemy, sentenced to two years' imprisonment, and brought directly to the Kelapa Dua jail on May 9, 2017, his supporters' reaction was extraordinary. Supporters and sympathizers in Jakarta 
lit over a million candles and sent thousands of flower boards to the Jakarta City Hall, the National Monument, and the Central Police Headquarters; similar activities were undertaken across Indonesia and even abroad. Communal interfaith prayers and nationalist songs were also involved. These were all intended to present a form of moral resistance against Ahok's electoral defeat and his subsequent imprisonment, and understood as a manifestation of their love for their country.

As Julia Daniel Kotan wrote in "Papan Bunga Balai Kota" (Kotan, 2017):

\begin{tabular}{|c|c|}
\hline $\begin{array}{l}\text { PAPAN BUNGA BALAI KOTA } \\
\text { Julia Daniel Kotan } \\
\text { Hamparan permadani membentangkan serenada } \\
\text { Tak menyapa subuh sampai senja memanggil } \\
\text { Beribu kepala menyembul } \\
\text { Tangan terulur } \\
\text { Apa yang kau cari bapa, mama dan semua? }\end{array}$ & $\begin{array}{l}\text { THE FLOWER BOARDS AT CITY HALL } \\
\text { Julia Daniel Kotan } \\
\text { A sea of tapestries crooning their serenade } \\
\text { From dawn 'til dusk calling } \\
\text { Thousands of heads bobbing } \\
\text { Hands outspread } \\
\text { What see you father, mother, all? }\end{array}$ \\
\hline $\begin{array}{l}\text { Kepak sayap elang hendak } \\
\text { Bertengger di puncak } \\
\text { Kotak-kotak menarikan air mata } \\
\text { Aksara bermakna lara dan suka } \\
\text { Serta asa yang teraniaya } \\
\text { Cinta terpatri di gunungan bunga } \\
\text { Tertancap di papan yang setia } \\
\text { Menerima apa yang terbersit } \\
\text { Dari hati pengirimnya... }\end{array}$ & $\begin{array}{l}\text { An eagle's wings beat as it } \\
\text { Stands upon the peak } \\
\text { Boxes dance with tears } \\
\text { Letters spell sorrow and joy } \\
\text { And a hope assailed } \\
\text { Love flows upon the mountain of flowers } \\
\text { Planted upon boards that loyally } \\
\text { Accept that revealed } \\
\text { By the heart of the sender ... }\end{array}$ \\
\hline $\begin{array}{l}\text { Beribu papan bunga membanjir } \\
\text { Semilir terukir benih terima kasih } \\
\text { Dan bakti dari ksatria yang kalah } \\
\text { Yang lemah bukan karena payah } \\
\text { Tetapi melawan kekuatan }\end{array}$ & $\begin{array}{l}\text { Thousands of flower boards flood } \\
\text { Imbued with the seeds of gratitude } \\
\text { And the service of a knight defeated } \\
\text { Weakened not by strain } \\
\text { But from fighting power }\end{array}$ \\
\hline $\begin{array}{l}\text { Aksimu memburu tumbuhkan cintamu } \\
\text { Kesucianmu dalam kasus bancaan } \\
\text { Melibatkan rombongan predator } \\
\text { Yang bukan lagi sekadar koruptor } \\
\text { Adamu bersih suci murni } \\
\text { Kan kami temani berdiang } \\
\text { Dalam abu dingin } \\
\text { Membakar kayu pilihan pada tersuci } \\
\text { Kau akan makin berkilau karena ditempa } \\
\text { Di kawah candradimuka yang membara }\end{array}$ & $\begin{array}{l}\text { Your actions spread your love } \\
\text { Your sanctity in face of those } \\
\text { Droves of predators } \\
\text { No longer mere corruptors } \\
\text { You are clean, pure, pious } \\
\text { We will accompany you } \\
\text { In the cold ashes } \\
\text { As we burn the sacral wood chosen } \\
\text { You will shine as you are forged } \\
\text { In the burning crater of candradimuka }\end{array}$ \\
\hline $\begin{array}{l}\text { Zaman 'kan membuktikan perumpamaan } \\
\text { Siapa emas yang menahan panas } \\
\text { Menziarahi hidup dengan perubahannya } \\
\text { Mengundang mata dengan tenang } \\
\text { Bergetar dada meratapi wajah senyum } \\
\text { Dipeluk penuh cinta oleh sang pencipta } \\
\text { Berjejal manusia mengulurkan tangan } \\
\text { Menyentuh seujung bajumu } \\
\text { Bahagia } \\
\text { Ditingkah teriakan bernada pedis } \\
\text { Perlambang ketabahan dan kesakitan } \\
\text { Tertahan tangisan anak negeri }\end{array}$ & $\begin{array}{l}\text { Time will prove true the adage } \\
\text { Whatever is gold withstands the heat } \\
\text { Bringing life with its change } \\
\text { Drawing the eye calmly } \\
\text { Quivering chest under a smiling face } \\
\text { Embraced lovingly by the creator } \\
\text { As droves of humanity give their hands } \\
\text { Touch the tips of your shirt } \\
\text { Joyfully } \\
\text { As cries ring out } \\
\text { Signifying the pains and struggles } \\
\text { Of people holding back tears }\end{array}$ \\
\hline $\begin{array}{l}\text { Biarlah mengalir sampai ke hilir } \\
\text { Air mata } \\
\text { Simpati } \\
\text { Empati } \\
\text { Belas kasih } \\
\text { Kerinduan } \\
\text { Dukungan }\end{array}$ & $\begin{array}{l}\text { Let them flow downriver } \\
\text { Tears } \\
\text { Sympathy } \\
\text { Empathy } \\
\text { Love } \\
\text { Longing } \\
\text { Support }\end{array}$ \\
\hline $\begin{array}{l}\text { Untukmu } \\
\text { Cinta itu telah menemukan } \\
\text { Tempat pelariannya }\end{array}$ & $\begin{array}{l}\text { For you } \\
\text { Love has found } \\
\text { Its escape }\end{array}$ \\
\hline $\begin{array}{l}\text { Catatan: kisah heroik yang tak kentara } \\
\text { Depok, } 26042017\end{array}$ & $\begin{array}{l}\text { Note: An intangible tale of heroism } \\
\text { Depok, } 26042017\end{array}$ \\
\hline
\end{tabular}

The above poem firmly asserts the poet's belief that Ahok had worked hard and made progress despite the racially and religiously-charged attacks against him. She was staunchly opposed to identity politics becoming used as a weapon, as it proved detrimental to the social harmony that Indonesia's founding fathers had dedicated themselves towards creating. 
Finally, the poem "Tetap Mantan Terindah" (Still the Best Ex) was written by Wanda Ponika as an exploration of Ahok's ability to endure and stand strong in the face of his opponents' attacks. He maintained his courage and heroism even after spending two years in prison. Wanda also explores Ahok's activities after his release.

\begin{tabular}{|c|c|}
\hline $\begin{array}{l}\text { TETAP MANTAN TERINDAH } \\
\text { Wanda Ponika } \\
\text { Saat datang gempuran lawan } \\
\text { Dia begitu kuat bertahan } \\
\text { Sampai tiba saat ditahan } \\
\text { Dia berdiri tegak bak pahlawan.... }\end{array}$ & $\begin{array}{l}\text { STILL THE BEST EX } \\
\text { Wanda Ponika } \\
\text { When the opponents' attacks came } \\
\text { He stood oh so strongly } \\
\text { Until time came for prison } \\
\text { He stood firm like a hero.... }\end{array}$ \\
\hline $\begin{array}{l}\text { Saat hari kebebasan tiba } \\
\text { Begitu banyak praduga } \\
\text { Lawan ketar ketir } \\
\text { Pendukung sumringah berharap.... }\end{array}$ & $\begin{array}{l}\text { When the day of freedom came } \\
\text { So many prejudices } \\
\text { His opponents raged } \\
\text { His supporters trembled }\end{array}$ \\
\hline $\begin{array}{l}\text { Tapi hidup bak film } \\
\text { Tak ada yang bisa ditebak } \\
\text { Saatnya lawan yang sumringah } \\
\text { Pendukung hanya tersenyum getir.... }\end{array}$ & $\begin{array}{l}\text { But life is like a film } \\
\text { Nothing is predictable } \\
\text { It's time for his opponents to tremble } \\
\text { As his supporters simply smile .... }\end{array}$ \\
\hline $\begin{array}{l}\text { Ternyata dia berubah } \\
\text { Ingin terlahir lagi } \\
\text { Menjadi sosok baru } \\
\text { Membuang semua cerita lalu.... }\end{array}$ & $\begin{array}{l}\text { Turns out he'd changed } \\
\text { Sought to be reborn } \\
\text { Become a new man } \\
\text { Forget all tales of the past .... }\end{array}$ \\
\hline $\begin{array}{l}\text { Ternyata dia tak runtuh oleh lawan } \\
\text { Dia meruntuhkan dirinya sendiri } \\
\text { Pendukung gigit jari } \\
\text { Lawan menonton sembari menari.... }\end{array}$ & $\begin{array}{l}\text { He did not fall because of his foes } \\
\text { He made himself fall } \\
\text { Supporters bit their tongue } \\
\text { His opponents watched and danced.... }\end{array}$ \\
\hline $\begin{array}{l}\text { Sekarang dia manusia bebas } \\
\text { Dia berhak atas hidupnya } \\
\text { Bebas menentukan langkah } \\
\text { Bebas merangkai masa depan.... }\end{array}$ & $\begin{array}{l}\text { Now he's a free man } \\
\text { He has a right to his own life } \\
\text { The freedom to choose his steps } \\
\text { The freedom to weave his future.... }\end{array}$ \\
\hline $\begin{array}{l}\text { Semoga dia ingat } \\
\text { Dulu pernah tersandung } \\
\text { Jangan sampai sekarang terpeleset } \\
\text { Waspadalah } \\
\text { Jangan mabuk kebebasan.... }\end{array}$ & $\begin{array}{l}\text { Hopefully he remembers } \\
\text { How he had fallen } \\
\text { He must not slip } \\
\text { Be careful } \\
\text { Not to get drunk off freedom... }\end{array}$ \\
\hline $\begin{array}{l}\text { Kami pernah menyalakan lilin untukmu } \\
\text { Jutaan tjahaja kecil berkumpul } \\
\text { Teriring doa untukmu } \\
\text { Semoga kau masih bisa bertjahaja.... }\end{array}$ & $\begin{array}{l}\text { We'd lit candles for you } \\
\text { Millions of tiny lights becoming one } \\
\text { Guided by prayers for you } \\
\text { That you would continue to shine .... }\end{array}$ \\
\hline $\begin{array}{l}\text { Selamat tinggal pahlawan } \\
\text { Terimakasih atas semua pelajaran } \\
\text { Terimakasih atas semua warisan } \\
\text { Terimakasih atas semua pengabdian } \\
\text { Terimakasih atas semua kenangan.... }\end{array}$ & $\begin{array}{l}\text { Goodbye, o hero } \\
\text { Thank you for the lessons } \\
\text { Thank you for the legacy } \\
\text { Thank you for the service } \\
\text { Thank you for the memories.... }\end{array}$ \\
\hline Dia tetap mantan terindah. & He is still the best ex \\
\hline
\end{tabular}

This poem shows that, as Wanda had hoped that Ahok would return to politics and seek a new leadership position, she felt disappointed that Ahok had been "reborn". He had emerged as someone who followed the rules of conventional etiquette, whose life followed a new trajectory. Ultimately, this poem frames Ahok as a cherished memory. For this, the poet expresses her gratitude and continues to identify him as the best governor in the history of Jakarta.

\section{Conclusion}

During the 2017 Jakarta gubernatorial election, poetry was used extensively by Fadli Zon to attack Ahok (his political opponent) and insult his leadership. This study has shown that Fadli produced three poems, namely "Tukang Gusur" (The Evictor, 2016), "Tak Pernah Terbayang" (Never Imagined, 2016), and "Sajak Sang Penista" 
(A Blasphemer's Verse, 2017), as a form of character assassination. These poems contributed significantly to the polarization of Jakartan and Indonesian society. Furthermore, the poems "Tak Pernah Terbayang" (2016) and "Sajak Sang Penista" (2017) exploited sectarian and religious affiliations to incite readers and urge them to participate in a series of protests against Ahok and his leadership. Ultimately, Ahok's electability fell from $\mathbf{7 3 \%}$ to $34.1 \%$, and he lost the gubernatorial election. Furthermore, Ahok was sentenced to two years' imprisonment (a harsher sentence than sought by the prosecutor) as he had been 'convincingly proven to have committed the crime of blasphemy'.

Was Ahok a cruel "evictor" and "blasphemer"? It is true that Ahok had been found guilty of blasphemy by the Indonesian courts, and that he had spent two years in prison for blasphemy. However, four other poems challenge this view: Ade Irawan's "Puisi untuk Ahok" (A Poem for Ahok, 2017), Rizal Kyoto's "Puisi untuk Ahok" (A Poem for Ahok, 2017), Julia Daniel Kotan's "Papan Bunga Balai Kota" (The Flower Boards of City Hall 2017), and Wanda Ponika's "Tetap Mantan Terindah" (Still the Best Ex, 2019). These poems not only support Ahok, but also present their own facts and arguments that support their view.

Post-truth refers to a situation in which facts shape public opinion less significantly than emotion and personal belief. In such a situation, there is no difference between fact and fiction. Why are lies so spellbinding? According to Hanna Arendt, lies "speak" to people because they reaffirm existing emotions and beliefs even when the facts suggest otherwise. In the current post-truth era, information is woven out of whole cloth, creating confusion and ambiguity in how reality is interpreted; this can result in the creation of political myths, unrest, and enmity between different social groups (Llorente, 2017).

The poems of Fadli Zon - at the time a member of the Gerindra Party and the deputy speaker of the of the People's Representative Council-contributed to the devaluation of the truth. As such, they created a demagogic political narrative, one that incited hatred and unrest. These poems, embodying the spirit of the post-truth era, emphasized emotion and sensation over objectivity and rationality, thereby polarizing voters in the lead-up to the gubernatorial elections and drawing electoral support for Anies Baswedan. Poetry, therefore, was successfully used as a medium for gaining power. Ahok not only lost the election, but was also found guilty of blasphemy.

Nonetheless, it is important to understand that such emotional and sensational poems were not simply accepted. Many Indonesians continued to believe that Indonesia's political and electoral system could remain rational and objective. When Ahok was imprisoned, supporters sent flower boards and lit candles throughout Jakarta, Indonesia, and even several foreign cities. As stated by Wanda Ponika, Ahok remained "still the best ex".

\section{Acknowledgements}

This article was funded by the Institute of Research and Public Service (LPPM), Universitas Sanata Dharma, through its 2019 budget. The author would like to express his gratitude to LPPM Universitas Sanata Dharma for funding this research.

\section{Bibliography}

[1] Anggraeni, V.A. (2018, September 06). Election History in Indonesia. https://www.goodnewsfromindonesia. id/2018/09/06/sejarah-pemilu-di-indonesia.

[2] Barker, C. (2000). Cultural Studies, Theory and Practice. London: Sage Publication.

[3] Bressler, C.E. (2007). Literary Cristicism: An Introduction to Theory and Practice (Fourth Edition). New Jersey: Pearson Prentice Hall.

[4] Eagleton, T. (1983). Literary Theory: An Introduction. Minneapolis: University of Minnesota Press.

[5] Fauzi, G. (2016, November 24). Chronology of the Buni Yani Case, Spread Video of Ahok Problem Al Maidah. CNN Indonesia.

[6] Fodouop, C.K., \& Greene, A. (2018, January Sunday, the 14th of January 2018.). Upon the Political Role of Poetry. Sciences Po Paris.

[7] Geertz, C. (1973). Thick Description: Toward an Interpretive Theory of Culture?" in The Interpretation of Cultures: Selected Essays. New York: Basic Books.

[8] Geertz, C. (1998). Deep Play: Notes on the Balinese Cockfight" in The Critical Tradition: Classic Texts and Contemporary Trends (David H. Richter, Ed.). Boston: Bedford Books.

[9] Haryanto, A. (2016). Four Reasons the Kalijodo Area Needs to be Regulated, Liputan6.com. Jakarta: Liputan6.com. 17 Feb 2016, 19:57 WIB. 
[10] Ian Davidson, J.L. (2019). "Political Poetry" Walton. http://www.academia.edu/24740962/Political_ Poetry.

[11] Irawan, A. (2017, April 5). Poetry for Ahok. Tribune, pp. https://www.tribunnews.com/seleb/2017/04/05/ ade-irawan-tulis-puisi-untuk-ahok-netizen-terharu .

[12] Jameson, F. (1981). The Political Unconscious: Narrative as a Social Symbolic Act . London: Methuen.

[13] Kotan, J.D. (2017). We are Indonesia. Jakarta: Publisher of Our Vocabulary.

[14] Kühne, W. (2010). The Role of Elections in Emerging Democracies and Post-Conflict Countries Key Issues, Lessons Learned and Dilemmas. Berlin, Germany: Friedrich-Ebert-Stiftung I International Policy Analysis Department for Global Policy and Development Hiroshima.

[15] Kyoto, R. (2017, Desember 16). Poetry for Ahok. Kompasiana.com, pp. https://www.kompasiana.com/ rizalkyoto/5a34f2355e137304ce159653/puisi-untuk-ahok?page=all 16 Desember 2017.

[16] Lin, D.T. (2019). Language and Political Psychology: Can Grammar Influence Electability? . GEMA Online® Journal of Language Studies Volume 19(3), August 2019 http://doi.org/10.17576/gema-20191903-01, 1-21.

[17] Llorente, J.A. (2017, March). The post-truth era: Reality vs. Perception. UNO Magazine, March 2017.

[18] Mesfin, B. (2008). Democracy, elections \& political parties A conceptual overview with special emphasis on Africa ISS Paper 166. Pretoria/Tshwane: Institute for Security Studies. Brooklyn Square .

[19] Nailufar, N.N. (2017, April 15). Why is the level of satisfaction with Ahok-Djarot not directly proportional to electability? Kompas.com.

[20] Patji, A.R. (2015). "Political Poetry" in the 2014 RI Presidential Election Campaign. Journal of Society \& Culture, 17(1), 1-16.

[21] Peringatan, P.B. (1996). Hundred Years of Hajj Agus Salim, Compiled by the Commemorative Book Committee (Second Printing ed.). Jakarta: Sinar Harapan.

[22] Ramdhani, J. (2017, April 13). Second Round of Pilgub DKI LSI Denny JA: Satisfaction Rate of AhokDjarot Reaches $73 \%$. Detik news.

[23] Reza Babagolzadeh, M.S. (2017, September 5). George Herbert's The Temple: A Religious Rhyme or Political Poetry? International Journal of Applied Linguistics \& English Literature. Vol. 6 No. 5; September 2017.

[24] Saroh, M. (2016, Oktober 4 ). Ahok-Djarot Electability Declines, LSI Said. tirto.id.

[25] Sisk, T.D. (2017). Elections, Electoral Systems and Party Systems A Resource Guide . Strömsborg SE-103 34 Stockholm Sweden: International IDEA on Electoral Integrity.

[26] Sularto, S. (2004). Haji Agus Salim (1884-1954): about War, Jihad, and Pluralism. Jakarta: Gramedia Main Library.

[27] Taum, Y.Y. (2015). Literature and Politics: Representation of the 1965 Tragedy in the New Order State. Yogyakarta: Sanata Dharma University Press.

[28] Taum, Y.Y. (2017). "Discursive Literary Criticism: A Reposition". Literary Criticism National Seminar "Literary Criticism that Motivates and Inspires" 15-16 August 2017. Jakarta: Language Development and Development Agency.

[29] Wangchuk, T. (2018). Verses of Praise and Denigration: Finding Poetic Creativity in the Tibetan Election in Exile. HIMALAYA, the Journal of the Association for Nepal and Himalayan Studies, 38 Number 1 Article 20( June 2018). 